\title{
Seasonal Variation of Heavy Metals in Playgrounds of Public Schools within Owerri Metropolis, Imo State, Nigeria
}

\author{
Verla Evelyn Ngozi ${ }^{1}$, Verla Andrew Wirnkor ${ }^{2}$, Ugwulor Louis ${ }^{3}$ \\ ${ }^{1}$ Department of Environmental Technology, School of Environmental Technology Federal \\ University of Technology, P.M.B.1526, Owerri, Imo State Nigeria \\ ${ }^{2}$ Department of Chemistry, Imo State University, P.M.B.2000, Owerri, Imo State, Nigeria \\ ${ }^{3}$ Department of Human Kinetics and Health Education, University of Port Harcourt, Choba, \\ P.M.B.5323, Port Harcourt, Rivers State, Nigeria \\ E-mail address: n.verla@evtfuto.com, verlaandreww@imsu.edu.ng, \\ ugwulor@yahoo.com
}

Keywords: variability; playground soils; anthropogenic; safe environment; toxic metals

\begin{abstract}
Knowledge of variation in metal concentrations of playground soil in dry and rainy season could assist in controlling metal accumulation in children if playtime is regulated according to seasons. The present investigation was designed to find out the existence and trend of such variation. Thirty six surface soil samples from nine playgrounds of Owerri metropolis were collected during the dry season and rainy seasons of 2012 and 2013 and were digested in Pyrex glassware using nitric acid. Total heavy metal concentration was determined by AANALYST 400 Perkin Elmer absorption spectrophotometer and coefficient of variation was used to categorize variability. Results demonstrated significant seasonality for all five heavy metals with major variability observed between dry and the rainy season. Metal concentrations showed zinc as highest metal in both seasons whereas cobalt was lowest metal with $\mathrm{Ni}$ occasionally being lowest in the rainy season. The variation of metals concentrations in playground soil especially in the rainy season may add to the body burden of the children, and therefore reduced hours of play during this season is recommended.
\end{abstract}

\section{INTRODUCTION}

Pollution of surface soil with toxic heavy metals has become a major global concern due to growing health risks to the public $[1,2]$. Child health has been linked to playgrounds and type of play. According to the National Program for Playground Safety (NPPS), based at the University of Northern Iowa, children need 60 minutes of play with moderate to vigorous activity every day to grow up to a healthy weight. NPPS developed a four-step national action plan for playgrounds: provide proper playground supervision; design age-appropriate playgrounds; provide proper surfacing under and around equipment; and keep equipment properly maintained. Urbanization, industrialization and other aspect of modernization have caused the generation of huge quantity of solid, liquid and gaseous waste resulting in soil contamination. Many industrial activities such as surface treatment, galvanizing, electroplating, pickling, paper, chloro-alkali, batteries, and textiles make use of heavy metals. Due to the improper management of the waste generated from these types of industries, playground soils are being contaminated, more so when located in and around industrial areas. [3]

Elevated heavy metals in playgrounds soil is due to natural processes such as atmospheric deposition, erosion, mineral weathering as well as anthropogenic sources in urban areas such as industrial and agricultural activities amongst the major source of these metals in the environment. However studies have reveal that traffic emissions are unanimously considered the major contributor of metal concentrations on playground soil and dust [4]. 
Exposure to heavy metal contamination has been found to cause such problems to children as kidney damage, liver damage, carcinogenic, paralysis, convulsions depression and pneumonia and etc [4]. These exposure problems are exacerbated by children vulnerability. Researchers have been focusing on quantifying these heavy metals and their assessments on children's environment and facilities $[5,6,7]$. Past studies have reported ingestion of playground dust with significant amounts of metals particularly arsenic. Thus numerous researchers were conducted on child health risk assessment relating to metals $[8,9,10]$. By way of culture, Nigerian children have direct contact with soil. Aliyu et al., [12] investigated, lead contamination of soil in children's playgrounds of some selected schools in Kaduna State with emphasis on the premises of nursery/primary schools. Results showed some variations from the background lead levels.

Seasonal variations in agricultural activity, storm water runoff, interflow and atmospheric deposition has strong effects on concentration of heavy metals [13] in the environment including playground soil. Thus, characterization of seasonal variability in surface soil quality is imperative for evaluating temporal variations of playground soil pollution from natural or anthropogenic contributions. Recently there has been growing awareness of the environmental impact of contaminated soil on play grounds [14]. However, in Owerri metropolis publications covering the subject of heavy metal contaminations especially on children playgrounds are lacking.

It is clear that such information aids our understanding of heavy metal behavior in the environment and is therefore of widespread interest. The hypothesis tested was that there is a seasonal variation in heavy metal concentrations during the year.

\section{MATERIALS AND METHODS}

\subsection{Site description}

Owerri municipal is one of the three local government areas (LGAs) that make up Owerri city, the capital of Imo state of Nigeria set in the heart of the Igboland. Its population density ranks fourth as of 2006 census. It lies within coordinates: $5^{\circ} 29^{\prime} \mathrm{N} 7^{\circ} 2^{\prime} \mathrm{E} / 5.483^{\circ} \mathrm{N} 7.033^{\circ}$ with tropical climate. This area is under heavy traffic all year round since and is home to the biggest and modern market and the seat of state government. Even though there are no industries, connecting roads to neighboring states pass through the metropolis thereby increasing traffic volume.

\subsection{Sampling of soil}

Nine different sampling sites were taken from playgrounds along major roads connecting Owerri municipality in Imo state as follows: Surface soil or dust samples at $0-5 \mathrm{~cm}$ depth were collected in the months of January (dry season) and June (rainy season) of 2012. At each sampling site, a "W" shaped line was drawn on a 2 x $2 \mathrm{~m}$ surface along which samples were collected from five points into previously treated polythene containers using a perforated container to allow water to drain.

\subsection{Digestion of soil samples}

1 gram of the soil samples were digested in a Pyrex glassware using $20 \mathrm{mls}$ of $4 \mathrm{~N} \mathrm{HNO}_{3}$ acid at $90^{\circ} \mathrm{C}$ for $6 \mathrm{hrs}$. The mixture were then filtered into a $25 \mathrm{mls}$ standard volumetric flask and made up to the mark with deionized water. All laboratory glassware and plastic wares were first washed with high grade laboratory soap, rinsed with deionized water and soaked in $10 \%$ nitric acid (overnight), then rinsed again with double deionized water. All reagents used in this work were of analytical grade.

\subsection{Determination Heavy Metal in Soil Samples}

The total heavy metal concentration in the soil samples was determined by the use of The AANALYST 400 Perkin Elmer absorption spectrophotometer. Quantification was carried out using appropriate calibration curves prepared in the same acid matrix with standard metal solutions for atomic absorption spectrophotometer (Zhu et al., 2008). 


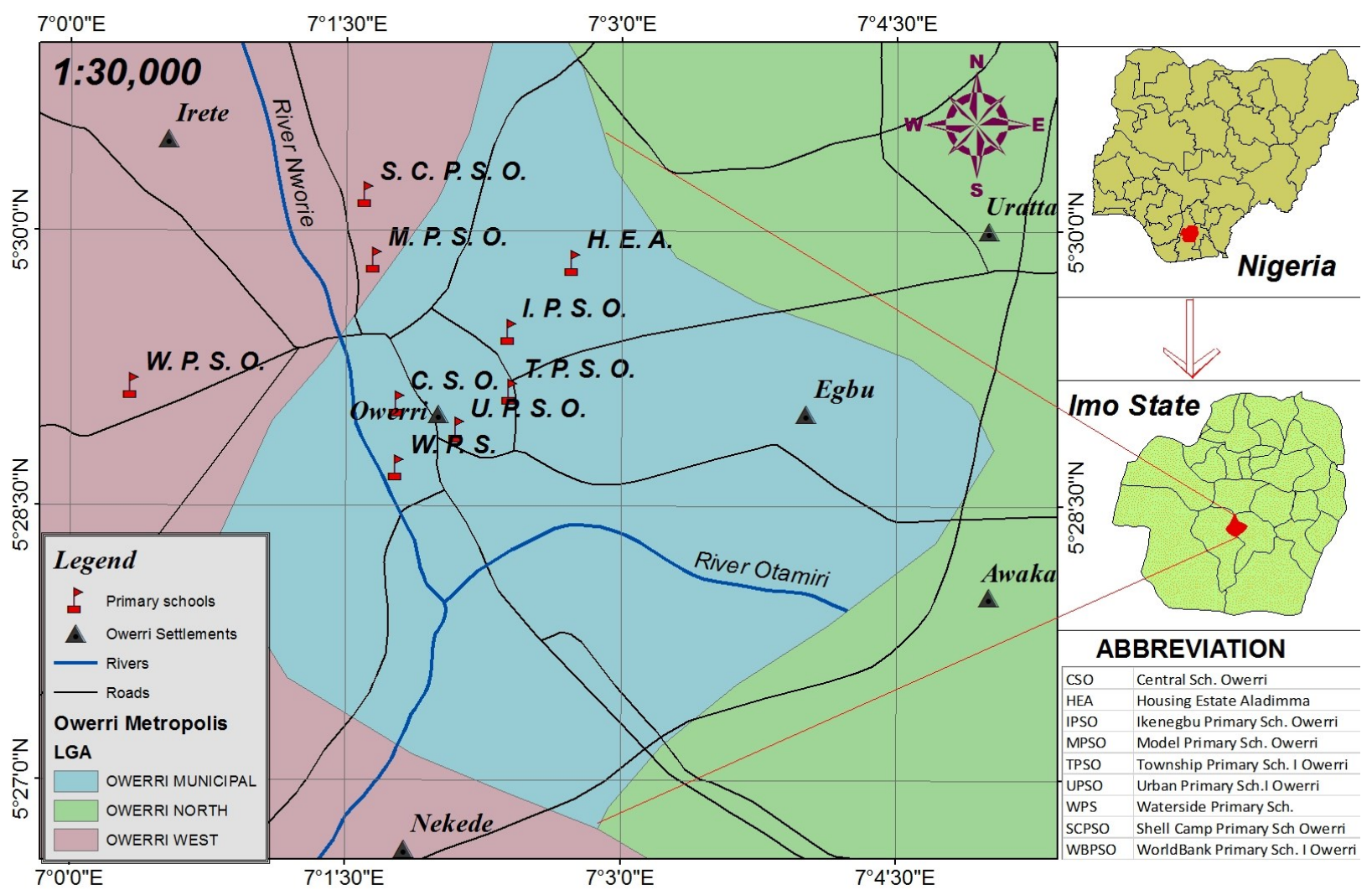

Fig 1: Map of Owerri metropolis showing sampling location

Samples were sundried for two days, then oven dried at $50^{\circ} \mathrm{C}$ for 12 days; grind in acid-washed porcelain mortar with pestle. The soil samples were pooled together, treated to coning and quartering to obtain a small laboratory sample (Verla, 2007). The samples were sieved through a $200 \mu \mathrm{m}$ sieve in order to normalize variations in grain size distributions. The samples were store in polythene containers with caps for further analysis (Jaradat et al., 1999).

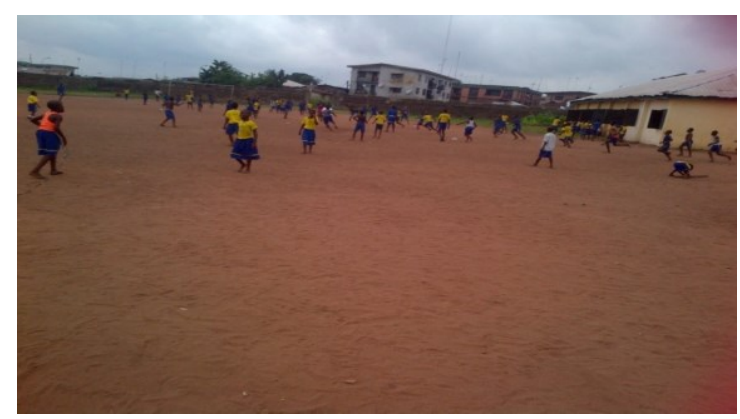

Fig 2: Typical playground of public school in Owerri metropolis

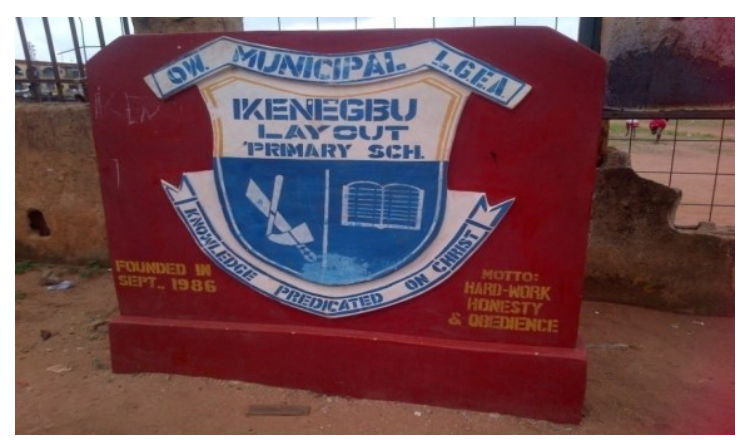

Fig 3: Typical playground open for public use in Owerri metropolis 


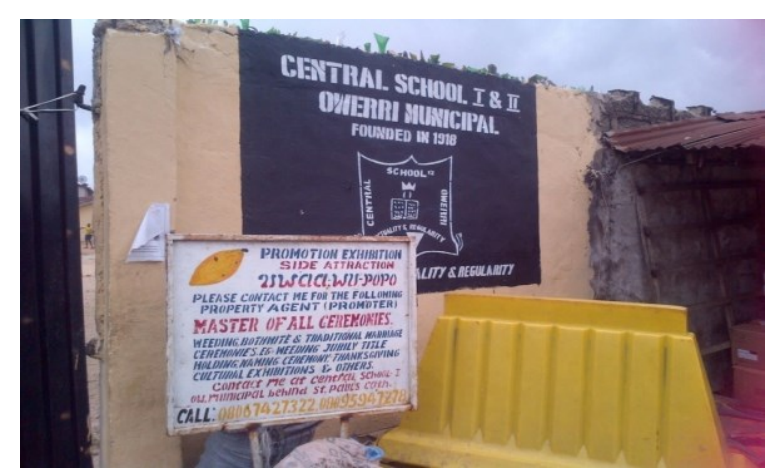

Fig 5: Typical playground used every time of the day in Owerri metropolis

\subsection{Quality control/Quality assurance}

Nitric acid $\left(\mathrm{HNO}_{3}\right)$ (suprapur), $\mathrm{HCl}$ (suprapur), sodium sulphate and potassium hydrogen carbonate were purchased from Merck (Fin lab. Owerri), while distilled water was used for heavy metals analyses; standard metal solutions for atomic absorption spectrophotometer were purchased from Fluka (Buchs, Switzerland). Appropriate calibration curves prepared in the same acid matrix with standard metal solutions for atomic absorption spectrophotometry were used for quantification. The detection limits (3x standard deviation of the baseline noise/sensitivity) of the analytical technique for each element were: $0.001 \mu \mathrm{g} / \mathrm{l}$ for $\mathrm{Mn}, 0.003 \mu \mathrm{g} / \mathrm{l}$ for $\mathrm{Co}, 0.002 \mathrm{mg} / \mathrm{l}$ for Ni, 0.001 $\mathrm{mg} / \mathrm{l}$ for $\mathrm{Zn}$ and $0.02 \mu \mathrm{g} / \mathrm{l}$ for $\mathrm{Cu}$. Values obtained were blank corrected and reported as mean value of the triplicates.

\subsection{Statistical Analysis}

Data analysis was done using SPSS version 17.0. Mean of the three results were recorded and the mean for each metal concentration in the nine playgrounds calculated. The standard deviation (SD) was determined and co-efficient of variation ( $\mathrm{CV} \%$ ) was used to determine the variation in heavy metal content between seasons. Variability was categorized as little variation $(\mathrm{CV} \%<20)$, moderate variation $(\mathrm{CV} \%=20-50)$ and high variation $(\mathrm{CV} \%>50)$.

\section{RESULTS AND DISCUSSION}

Results of metal concentration in soils of playgrounds of public schools within Owerri metropolis are summarized in figures 6- 9. Figures 6 shows that $\mathrm{Zn}$ was the most abundant metal in the dry season of 2012, followed by Mn. Cobalt was the least abundant and was insignificant in certain playgrounds as HEO, MNO and SCP. Ranking of metals in order of decreasing concentration in dry season of 2012 follow the order: $\mathrm{Zn}>\mathrm{Mn}>\mathrm{Cu}>\mathrm{Ni}>\mathrm{Co}$. Interestingly $\mathrm{Zn}$ was even more abundant in the rainy season (fig.7) than in the dry season. It was observed that $\mathrm{Zn}$ was generally higher than those of the in the dry season for all playgrounds. $\mathrm{Cu}$ and Ni showed the same trend as Zn whereas Co was barely noticeable only in schools CSO, TSO and WSP. From figures 7, ranking of metals concentrations follow the order: $\mathrm{Zn}>\mathrm{Cu}>\mathrm{Ni}>\mathrm{Mn}>\mathrm{Co}$. 


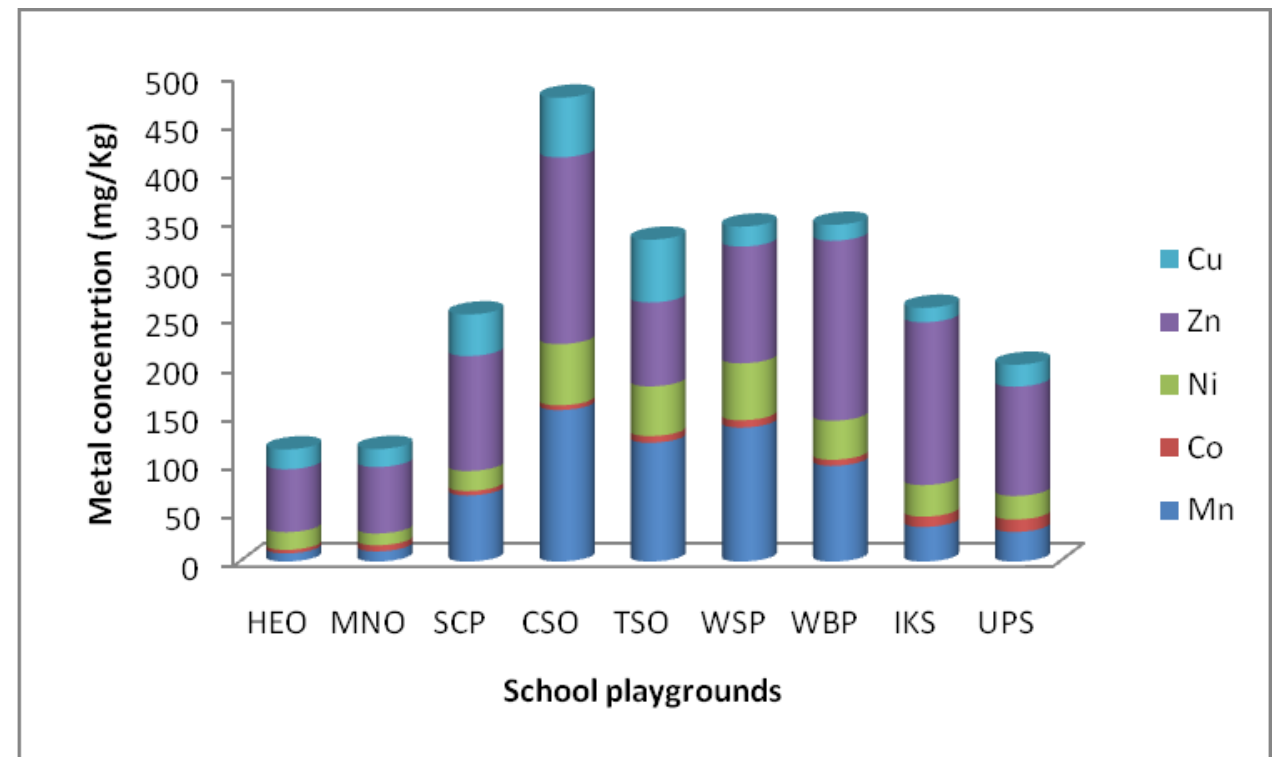

Fig. 6: Heavy metals concentrations in playgrounds soil for Dry season 2012

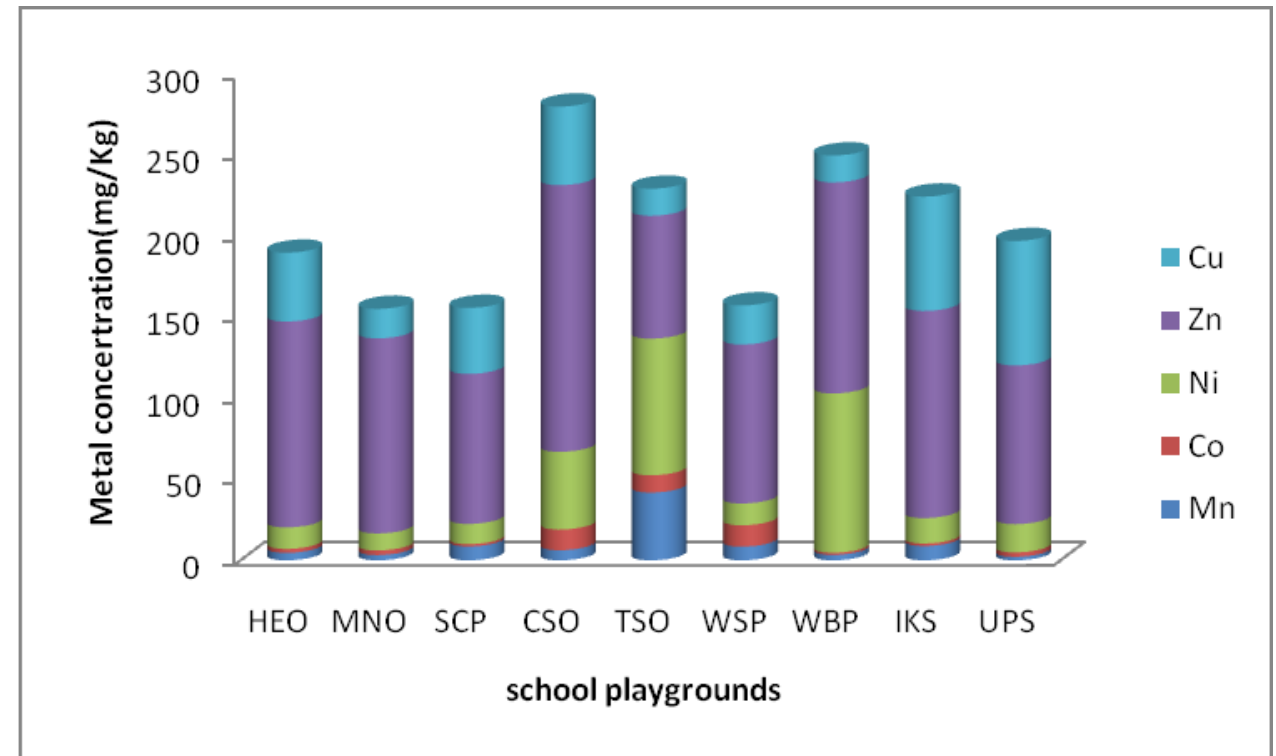

Fig. 7: Heavy metals concentrations in playgrounds soil for Rainy 2012

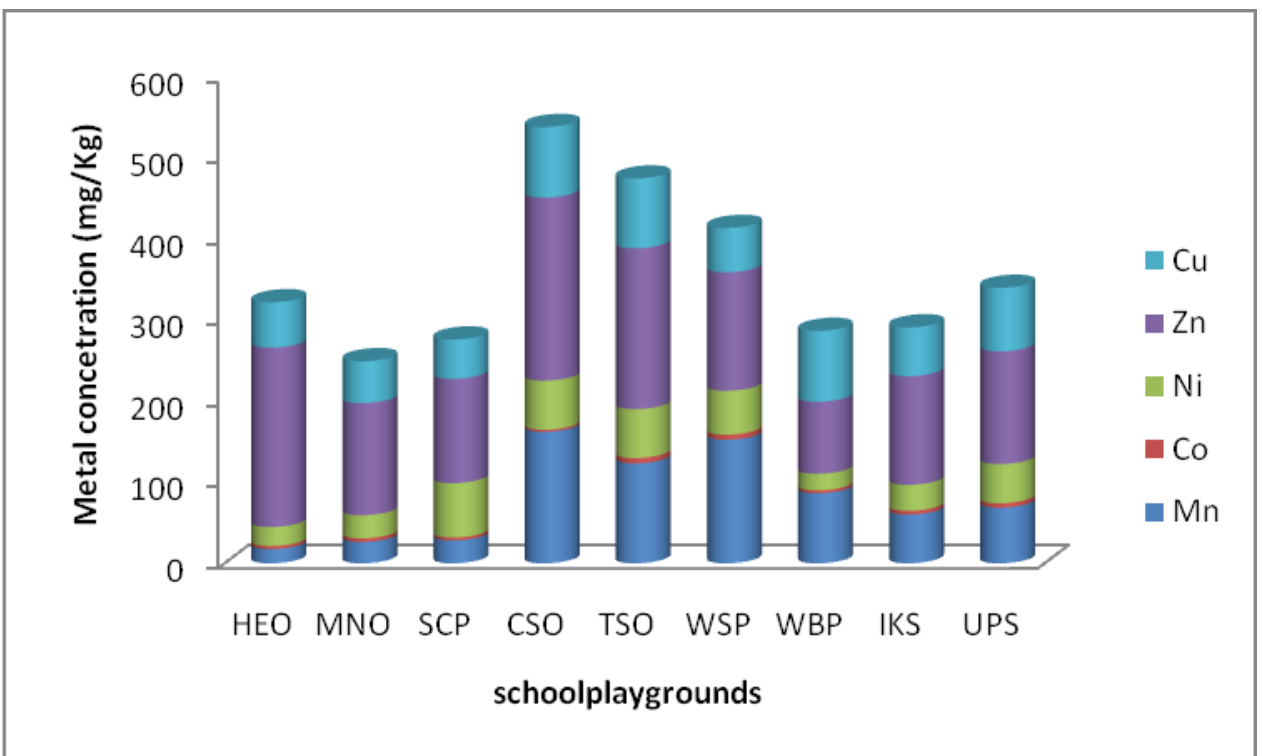

Fig 8: Heavy metals concentrations in playgrounds soil for Dry season 2013 


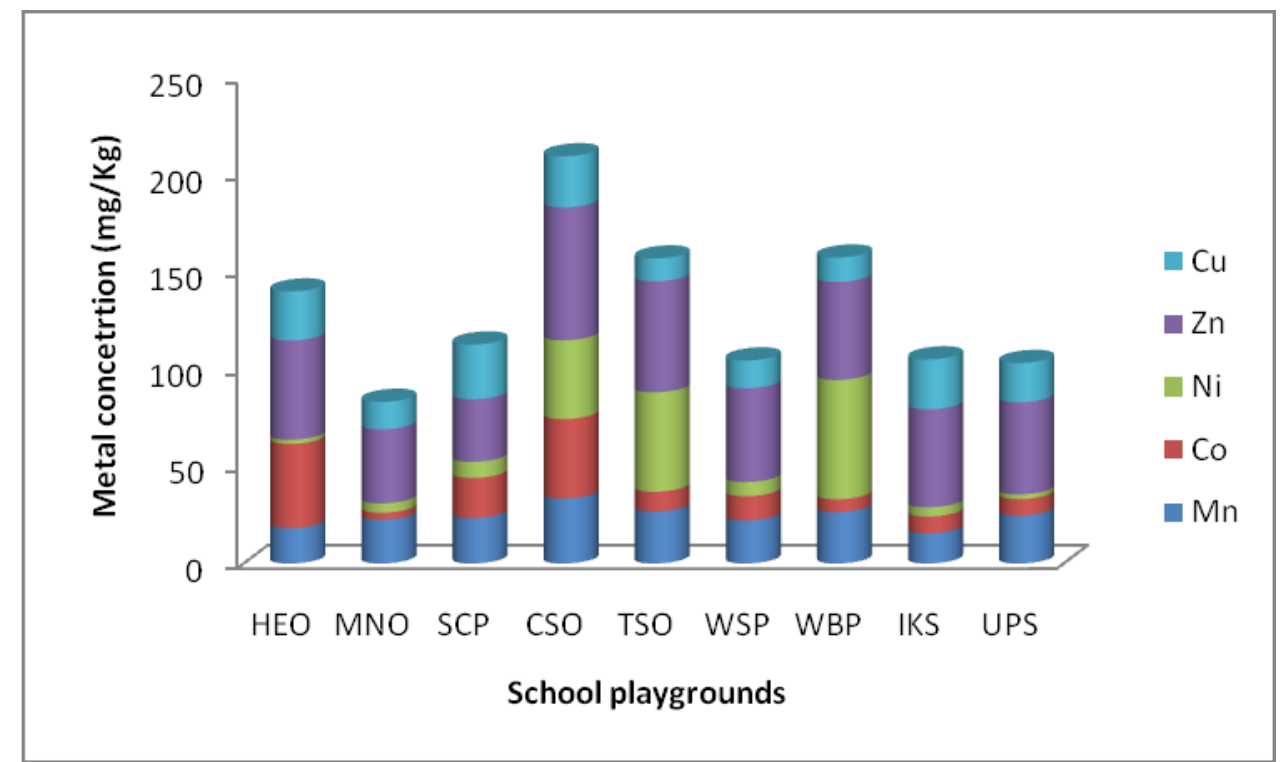

Fig. 9: Heavy metals concentrations in playgrounds soil for Rainy season 2013

Figure 8 shows that $\mathrm{Zn}$ was top in concentration amongst all metals studied, followed by $\mathrm{Cu}$ this time, dry season of 2013. Ranking trend followed was $\mathrm{Zn}>\mathrm{Cu}>\mathrm{Mn}>\mathrm{Ni}>\mathrm{Co}$.

As shown on figure 9 metal concentrations for rainy season 2013 had significant increase in cobalt at all playgrounds. However $\mathrm{Zn}$ was still highest in concentration for all playgrounds and so the trend was: $\mathrm{Zn}>\mathrm{Cu}>\mathrm{Mn}>\mathrm{Co}>\mathrm{Ni}$.

Table1. Some statistical parameters of heavy metals concentrations $(\mathrm{mg} / \mathrm{Kg})$ in playgrounds soil

\begin{tabular}{|c|c|c|c|c|c|c|c|c|c|c|}
\hline & \multicolumn{6}{|c|}{ Dry season 2012} & \multicolumn{3}{|c|}{ Rainy 2012} & \\
\hline & $\mathrm{Mn}$ & $\mathrm{Co}$ & $\mathrm{Ni}$ & $\mathrm{Cu}$ & $\mathrm{Zn}$ & $\mathrm{Mn}$ & Co & $\mathrm{Ni}$ & $\mathrm{Cu}$ & $\mathrm{Zn}$ \\
\hline Min. & 8.5 & 3.58 & 12.21 & 14.88 & 64.85 & 2.18 & 1.28 & 10.51 & 16.62 & 75.88 \\
\hline Max. & 156.2 & 12.81 & 63.2 & 64.68 & 192.5 & 41.87 & 13.21 & 98.48 & 76.89 & 164.74 \\
\hline Mean & 75.79 & 7.25 & 36.06 & 32.91 & 124.98 & 11.96 & 5.78 & 38.45 & 40.77 & 116.03 \\
\hline SDV & 54.77 & 3.17 & 18.61 & 19.76 & 48.16 & 21.38 & 5.14 & 34.22 & 22.89 & 26.59 \\
\hline $\mathrm{CV} \%$ & 72.27 & 47.72 & 51.61 & 59.95 & 38.53 & 178.76 & 88.93 & 88.99 & 5.14 & 22.91 \\
\hline \multicolumn{5}{|c|}{ Dry season 2013} & \multicolumn{6}{|c|}{ Rainy 2013} \\
\hline Min. & 17.56 & 2.56 & 20.56 & 48.6 & 88.95 & 15.47 & 3.63 & 2.18 & 11.75 & 32.34 \\
\hline Max. & 162.55 & 6.58 & 67.28 & 87.54 & 226.25 & 33.52 & 43.45 & 61.53 & 28.15 & 68.45 \\
\hline Mean & 82.40 & 4.58 & 43.95 & 67.89 & 158.01 & 23.84 & 18.42 & 22.44 & 19.86 & 49.54 \\
\hline SDV & 54.76 & 1.34 & 17.91 & 16.64 & 46.62 & 5.18 & 14.91 & 23.76 & 6.80 & 10.32 \\
\hline $\mathrm{CV} \%$ & 66.50 & 29.25 & 40.75 & 24.51 & 29.50 & 21.73 & 80.94 & 105.88 & 34.24 & 20.67 \\
\hline \multicolumn{5}{|c|}{ Mean 2012} & \multicolumn{6}{|c|}{ Mean 2013} \\
\hline Min. & 6.55 & 3.03 & 11.36 & 16.5 & 81.19 & 17.9 & 4.08 & 12.8 & 32.96 & 69.76 \\
\hline Max. & 82.19 & 10.38 & 69.35 & 55.05 & 178.62 & 98.04 & 23.66 & 55.92 & 56.80 & 147.35 \\
\hline Mean & 42.03 & 6.26 & 35.06 & 35.42 & 119.62 & 52.20 & 10.94 & 32.16 & 43.85 & 103.73 \\
\hline SDV & 31.16 & 2.78 & 22.89 & 13.91 & 33.39 & 29.1 & 7.10 & 15.26 & 7.99 & 26.8 \\
\hline $\mathrm{CV} \%$ & 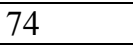 & 44 & 65 & 39 & 28 & 56 & 65 & 48 & 18 & 25 \\
\hline WHO & 1500 & - & 600 & 100 & 7000 & 1500 & - & 600 & 100 & 7000 \\
\hline BV & 25.00 & 8.00 & 40.00 & 30.00 & 90.00 & 25.00 & 8.00 & 40.00 & 30.00 & 90.00 \\
\hline
\end{tabular}

SDV: standard deviation, CV: coefficient of variation, WHO: world health organization standards; BV: background value.

The mean heavy metals concentrations $(\mathrm{mg} / \mathrm{Kg})$ in playgrounds for both dry and rainy seasons of 2012 and 2013 are shown on table 1. Threshold values of WHO Environmental Health Criteria No. 221, for children playgrounds were considered as the criterion of normal content of the five elements in the soils. 
Mean values show that the content of $\mathrm{Mn}$ in all nine playgrounds was lower than WHO threshold value while four playgrounds had concentrations lower than background value for Mn. However Mn concentration ranged from $8.5-75.79 \mathrm{mg} / \mathrm{Kg}$ with a high variability, 72.27 in the dry season of 2012. Mn concentrations had even lower range in the rainy season of $2012(2.18-21.38$ $\mathrm{mg} / \mathrm{Kg}$ ) and variability was almost three time the value in the dry season. In $2013 \mathrm{Mn}$ showed a range of $17.56-162.55 \mathrm{mg} / \mathrm{Kg}$. The average value for all playgrounds was over three times the background value of $25 \mathrm{mg} / \mathrm{Kg}$, however Mn had highest variability, 74 in the 2012 .

Though the standard value for Co was not found in literature, cobalt contents of all playgrounds were slightly higher than values reported for Queensland playgrounds by Mostersit 2008. Only playgrounds SCP, CSO and WSB had cobalt contents slightly above background values. Cobalt concentration in dry season 2012 ranged from $3.58-12.81 \mathrm{mg} / \mathrm{Kg}$ of 2012 . This had a variability of 47.72 categorized as moderate, whereas in rainy season Co showed even wider ranged with a high variability of 88.93. Cobalt variability was lowest in dry season of 2013 with a moderate variability, 29.25. Variability of cobalt had no significant difference in the rainy season of both 2012 and 2013. The mean values of cobalt for 2012 and 2013 were 6.26 and $10.94 \mathrm{mg} / \mathrm{Kg}$ respectively and were both comparable to background value of $8.00 \mathrm{mg} / \mathrm{kg}$.

The content of Ni was highest at WBP $(69.35 \mathrm{mg} / \mathrm{Kg})$ but this was only $11.60 \%$ compared to WHO threshold value of $(600 \mathrm{mg} / \mathrm{Kg})$. Playgrounds CSO, TSO and WBP had nickel contents higher than background value while the mean value was lower than background value.

Ni had showed high variability, 88.99 in rainy season than the high variability of 51.61 in the dry season. There was a significant difference in variability of $\mathrm{Ni}$ in 2013 where dry season had moderate 40.7 whereas the rainy season had high 105.88 . It was observed that the values of $\mathrm{Ni}$ concentrations were lower for dry season than rainy season despite very high variability. The mean values of $\mathrm{Ni}$ in 2012 and 2013 were below the background value for $\mathrm{Ni}(40.00 \mathrm{mg} / \mathrm{kg})$, however, $\mathrm{Ni}$ variability was categorized as high 65 in 2012 but moderate in 2013.

The average value of $\mathrm{Cu}(55.05 \mathrm{mg} / \mathrm{Kg})$ for all nine playgrounds was almost twice the background value $(30 \mathrm{mg} / \mathrm{Kg})$ but half the WHO threshold value.

$\mathrm{Cu}$ showed high variability (59.95) in the dry season of 2012 but low variability (5.14) in the rainy season. In 2013, all seasons showed moderate variability. Mean variability for 2012 was moderate (39) with metal concentrations ranging from $16.5-55.05 \mathrm{mg} / \mathrm{kg}$ whereas $\mathrm{Cu}$ variability in 2013 was low (18) with a narrow concentration range of 32.96 to $56.80 \mathrm{mg} / \mathrm{kg}$. The annual mean metal concentrations of $35.42 \mathrm{mg} / \mathrm{kg}$ and $43.85 \mathrm{mg} / \mathrm{kg}$ for 2012 and 2013 respectively were above $\mathrm{Cu}$ background value of $30 \mathrm{mg} / \mathrm{kg}$.

Zinc content was highest at as CSO $(178.62 \mathrm{mg} / \mathrm{Kg})$, this was as low as 40 times the threshold value $(7000 \mathrm{mg} / \mathrm{Kg})$. Except for TSO $(81.19 \mathrm{mg} / \mathrm{Kg})$ all other playgrounds had zinc contents higher than background value.

It was observed that all metals were lower than WHO threshold values but only in a few cases that the metals contents were lower than background values. The analysis shows that the contents of $\mathrm{Mn}, \mathrm{Ni}$ and $\mathrm{Cu}$ are higher than the other elements in the playgrounds in 2013. Zinc showed higher concentrations in most playgrounds and had highest concentration recorded in this work at CSO $(178.62 \mathrm{mg} / \mathrm{Kg})$ in 2012.

$\mathrm{Zn}$ concentrations showed a range of $64.85-192.50 \mathrm{mg} / \mathrm{Kg}$ in the rainy season representing a moderate variability of 38.53 in the dry season of 2012, whereas concentration ranged from 75.88 164.74, giving a low variability of 22.91 in the rainy season. In 2013, $\mathrm{Zn}$ concentrations showed a wider range of $88.95-226.25 \mathrm{mg} / \mathrm{kg}$ representing a moderate variability, 29.50 whereas the rainy season showed a narrow range $32.34-68.45$ with a low variability, 20.67. Mean annual of $\mathrm{Zn}$ concentrations were $199.62 \mathrm{mg} / \mathrm{kg}$ and $103.73 \mathrm{mg} / \mathrm{kg}$, values above background concentration of 90 $\mathrm{mg} / \mathrm{kg}$ representing moderate variability, 28 and high variability, 125 respectively. 
Table 2.Trends in seasonal variability for metals in the years 2012 and 2013

$\begin{array}{lll}\text { Year } & \text { Dry Season } & \text { Rainy Season } \\ \text { 2012: } \mathrm{Mn}>\mathrm{Ni}>\mathrm{Co}>\mathrm{Cu}>\mathrm{Zn} & \mathrm{Mn}>\mathrm{Cu}>\mathrm{Ni}>\mathrm{Co}>\mathrm{Zn} & \mathrm{Mn}>\mathrm{Ni}>\mathrm{Co}>\mathrm{Zn}>\mathrm{Cu} \\ \text { 2013: } \mathrm{Co}>\mathrm{Mn}>\mathrm{Ni}>\mathrm{Zn}>\mathrm{Cu} & \mathrm{Mn}>\mathrm{Ni}>\mathrm{Zn}>\mathrm{Co}>\mathrm{Cu} & \mathrm{Ni}>\mathrm{Co}>\mathrm{Cu}>\mathrm{Mn}>\mathrm{Zn}\end{array}$

The trends in seasonal variability observed for metals in the years 2012 and 2013 are shown on table 2. Annually variability was observed to follow the trends $\mathrm{Mn}>\mathrm{Ni}>\mathrm{Co}>\mathrm{Cu}>\mathrm{Zn}$ and $\mathrm{Co}>\mathrm{Mn}>\mathrm{Ni}>\mathrm{Zn}>\mathrm{Cu}$ in which $\mathrm{Mn}, \mathrm{Ni}$ and copper showed anthropogenic influence.

High variation is caused by anthropogenic rather than geogenic enrichment of the soil. Owerri municipality is a bee hive of commercial activities ranging from heavy construction of roads bridges and hotels to government owned estates. These could lead to heavy metals released in the environment.

5. CONCLUSIONSIn conclusion all five metals showed significant variation between dry and rainy season. Despite being highest in concentration, Zinc showed lowest variability. Overall variability could be ranked as follows: $\mathrm{Mn}>\mathrm{Co}>\mathrm{Ni}>\mathrm{Cu}>\mathrm{Zn}$. The metal variability is likely linked to metal concentrations and thus further research to find out this like is recommended.

\section{ACKNOWLEDGMENTS}

This work is completed as part of $\mathrm{PhD}$ thesis in the department of Pure and industrial chemistry, University of Port Harcourt. We thank members of the Research in Analytical Chemistry and Environmental Pollution Studies (RACEPS) and Doctoral students of Professor M. Horsfall Jnr and Professor Mrs. A. I Spiff. We are grateful for the financial assistance of Engr. Dr. Ernest Fonyuy of Slumberger, U.S.A. We express deep gratitude to the Director; Centre for Energy Research University of Nigeria Nsukka, for the use of certain scientific instruments.

\section{AUTHOR CONTRIBUTIONS}

Verla, Evelyn Ngozi and designed the study and Verla Andrew Wirnkor assisted her with sampling and data collection in the experiments. Ugwulor Louise advised on ethical issues and contacted the school head teachers and finally performed the statistical analysis of the data. All authors contributed in writing and critically discussed the results and implications for the manuscript and approved the final version.

\section{CONFLICTS OF INTEREST}

We declare no conflict of interest now and in the future.

\section{References}

[1]. Ahmed F., Ishiga H. Trace metal concentration in street dusts of Dhaka City, Bangladesh. Atmospheric Environment 40 (2006) 3835-3844.

[2]. Khashman O.A. Determination of metal accumulation in deposited street dusts in Amman, Jordan. Environmetal Geochemistry and Health 29 (1) (2007) 1-10.

[3]. Verla E.N, Verla A.W., Horsfall M Jr., Spiff A.I., Assessment Of Some Heavy Metal in Children's Playgrounds in Owerri Metropolis, Imo State, Nigeria. A conference paper presented Chemical Society of Nigeria Akwa Ibom 2015

[4]. Bhargava A.K., Gupta R., Bhargava S., Paridhi S. Effect of automobile exhaust on total N, P and heavy metals of road side sugarcane at district Saharanpur. Advance Plant Science 16 (2003) 557-560.

[5]. Chatterjjee A., Banerjee R.N. Assessment of trace metal distribution and contamination in surface soils of Amman, Jordan. Jordan Journal of Chemistry 4 (1) (1999) 77-87. 
[6]. Ericson J.E., Mishra S.I. Soil Lead Concentration and Prevalence of Hyperactive Behaviour among School Children in Ottawa,Canada. 1990.

[7]. Faiz Y., Tufail M., Javed M.T., Chaudhry M.M., Siddique N. Road dust pollution of Cd, Cu, $\mathrm{Ni}, \mathrm{Pb}$ and $\mathrm{Zn}$ along Islamabad Expressway, PakGistan. Microchemical Journal 92 (2009) 186192.

[8]. Fergussion J.E., Kim N.D. Trace elements in street and house dusts: Source and Speciation. Science of the Total Environment 100 (1991)125-150.

[9]. Gbadebo A.M., Bankole O.D. Analysis of potentially toxic metals in airborne cement dust around Sagamu, Southwestern Nigeria. Journal of Applied Science 7 (1) (2007) 35-40.

[10]. Higgs F.J., Mielke H.W., Brisco M. Soil lead at elementary public schools: Comparison between schools properties and residential neighborhoods of New Orlean. Environmental Geochemistry and Health 21(1997) 27-36.

[11]. Hrudey S.E., Chen W., Rousseaux C.G. Bioavailability in Environmental Risk Assessment. CRC Press, Boca Raton. 1996.

[12]. Aliyu, M.; Zakari, Y.I; Ibeanu, I.G.E.; Akpa, T.C. Evaluation of lead concentration levels of children's playground in Kaduna state schools. Bayero Journal of Pure and Applied Science 2 (2) (2009) $105-109$.

[13]. Joseph P. Mechanism of cancer carcinogenesis. Toxicology and Applied Pharmacology 238 (3) (2009) 272-279.

[14]. Lalor G.C. Review of cadmium transfers from soil to humans and its health effects in the Jamaican environment, Science of the Total Environment 400 (2008) 162-172.

[15]. Lanphear B., Weitzman M., Winter N., Eberly S., Yakir B., Tanner M., Emond M., Matte T., Lead contaminated house dust and urban children's blood lead levels. American Journal of Public Health 86 (1996) 1416-1421.

[16]. Lu X., Wang L., Lei K., Huaing J., Zhai Y., Contamination assessment of copper, Lead, Zinc, Manganese and Nickel in street dust of Boaji, N.W China. Journal of Hazardous Materials 161 (2009) 1058-1062.

[17]. Nriagu J.O. A history of global metal pollution. Science 272 (1996) 223-224.

[18]. Sekhar C, Chary N.S., Kamala C.T, Shanker H.F, Environmental pathway and risk assessment studies of the Musi River's heavy metal contamination-A Case Study, Hum. Ecology Risk Assessment 11(2005) 1217-1235.

[19]. Addo M.A., Darko E.O., Gordon C., Nyarko B.J.B, Gbadago J.K. Heavy Metal Concentrations in Road Deposited Dust at Ketu-South District, Ghana. International Journal Science Technology 2 1(2012) 28-29.

[20]. Pertsemli E., Voutsa D. Distribution of heavy metals in Lakes Doirani and Kerkini, Northern Greece. Journal of Hazard Material 148 (2007) 529-537.

[21]. Adebamowo E.O., Agbede O.A., Sridhar M.K.C., Adebamowo C.A., An evaluation of lead levels in residential paints sold in Nigeria markets. Indoor Bulletin of Environment 15 (2006) 551-554.

[22]. Li S., Cheng X., Xu Z., Han H., Zhang Q. Spatial and temporal patterns of the water quality in the Danjiangkou Reservoir, China. Hydrology Science Journal 54 (2009) 124-134.

[23]. Verla E.N., Verla A.W., Horsfall M.Jnr. A preliminary survey of heavy metals concentrations in children playgrounds within Owerri municipality, Imo State, Nigeria. Accepted by International Journal of Research in chemistry and environment 2014. 
[24]. Feng H., Han X., Zhang W., Yu L. A preliminary study of heavy metal contamination in Yangtze River intertidal zone due to urbanization. Marine Pollution Bulletin 49 (2004) 910 915.

[25]. Krishna A.K, Satyanarayanan M., Govil P.K Assessment of heavy metal pollution in water using multivariate statistical techniques in an industrial area: a case study from Patancheru, Medak District, Andhra Pradesh, India. Journal of Hazard Material 167 (2009) 366-373.

[26]. Asante K.A., Agusa T., Subramanian A., Ansa-Asare O.D., Biney C.A., Tanabe S. Contamination status of arsenic and other trace elements in drinking water and residents from Tarkwa, a historic mining township in Ghana. Chemosphere 66 (2007) 1513-1522.

[27]. De Miguel E., Iribarren I., Chacon E., Ordonez A., Charlesworth S. Risk-based evaluation of the exposure of children to trace elements in playgrounds in Madrid (Spain). Chemosphere 66 (2007) 505-513.

[28]. Taofeek A.Y., Tolulope O.O. Evaluation of some Heavy Metals in Soils along a Major Road in Ogbomoso, South West Nigeria. Journal of Environment and Earth Science 2 (8) (2012) 71-79.

[29]. Ouyang Y., Nkedi-Kizza P., Wu Q. Shinde D, Huang C. Assessment of seasonal variations in surface water quality. Water Research 40 (2006) 3800-3810.

[30]. Cidu R., Biddau R. Transport of trace elements under different seasonal conditions: effects on the quality of river water in a Mediterranean area. Applied Geochemistry 22 (2007) 27772794.

[31]. Zhang L., Zhou K. Background values of trace elements in the source area of pollution in surface water from Yangtze River in Nanjing Section, China. Bulletin of Environmental Contamination and Toxicology 82 (2009) 405-409.

[32]. Ramesh A., Nagendra-Prakash B.N., Sivapullaiaih P.V. Identification of source of heavy metal contamination in a site - a case study. International Journal of Environment and Pollution 51, (1/2) (2013) 91-105. 